\title{
КЛЮЧОВІ АСПЕКТИ СИСТЕМИ ПІДГОТОВКИ ЛІКАРЯ ЗАГАЛЬНОЇ ПРАКТИКИ У СЛОВАЧЧИНІ
}

\author{
Л. С. Бабінець, Н. Є. Боцюк, І. О. Боровик \\ ДВНЗ “Тернопільський держсавний медичний університет імені І. Я. Горбачевського МОЗ Украйни”
}

\section{KEY ASPECTS OF TRAINING OF GENERAL PRACTITIONERS IN SLOVAKIA}

\author{
L. S. Babinets, N. Ye. Botsyuk, I. O. Borovyk \\ SHEI "Ternopil State Medical University by I. Ya. Horbachevsky of MPH of Ukraine”
}

\begin{abstract}
У статті проаналізовано цінний для України досвід організації роботи системи охорони здоров'я у Словацькій Республіці на уніфікованих засадах країн СС та процесу підготовки кадрів для неї згідно з вимогами Болонської декларації у системі освіти, особливо в умовах реформування системи охорони здоров'я на засадах сімейної медицини та розмежування рівнів надання медичної допомоги населенню, а також інтеграції системи медичної освіти до Болонського процесу.

The article analyzes the valuable experience of Ukraine's health care system in Slovak Republic on the basis of unified EU and the process of training for it in accordance with the requirements of the Bologna Declaration in the education system, particularly in terms of healthcare reform on the basis of family medicine and division levels of health care, as well as the integration of medical education in the Bologna Process.
\end{abstract}

Вступ. У період реформування системи охорони здоров'я в Україні, коли відбувається розмежування рівнів надання медичної допомоги з пріоритетом первинної ланки і з перспективою впровадження страхової медицини, досвід країн, які йдуть у цьому процесі попереду, є надзвичайно цінним $[1,2]$. Досвід Словаччини по підготовці лікарів узагалі та лікарів загальної практики зокрема $є$ цінним для України тим, що у Словацькій Республіці відбувається перехід від централізованої системи охорони здоров'я до страхової медицини з елементами конкурентної приватної практики [3]. Відповідно до таких реалій відбулися зміни в підході до підготовки медичних кадрів [4]. Зокрема, важливим є досвід підготовки кадрів у Словацькому медичному університеті, де у листопаді 2013 року перебували на стажуванні працівники кафедри первинної медико-санітарної допомоги та загальної практики - сімейної медицини ДВНЗ “Тернопільський державний медичний університет імені I. Я. Горбачевського МОЗ України".

Основна частина. Братиславський медичний університет $є$ передовим освітнім закладом, членом IAMP (Міжнародної академії медичної групи), EUA (Європейської асоціації університетів), де, з гордістю зберігаючи традиції комплексної безперервної універ-

(ㄱ Л. С. Бабінець, Н. Є. Боцюк, І. О. Боровик ситетської освіти медичних працівників, працюють у рамках глобальної хартії університетів, визнаючи цінності демократії, гуманізму і взаєморозуміння [5]. Провідним завданням університету є забезпечення найвищих стандартів якості додипломної та післядипломної освіти в галузі охорони здоров'я нації однієї з найбільших людських цінностей. Ця місія університету передбачає проведення науково-дослідної діяльності у медицині, впровадження її результатів у практику та постійне вдосконалення вищої медичної освіти всіх ступенів, зокрема спеціалізованого i безперервного навчання всіх медичних, фармацевтичних та сестринських кадрів. Зауважимо, що додипломна підготовка кадрів у Словаччині проводиться виключно на безоплатній основі для студентів, тобто державним коштом, кількість місць обмежена, конкурс абітурієнтів дуже великий. Додипломна освіта знаходиться у підпорядкуванні та юрисдикції міністерства освіти цієї країни [6].

Післядипломна підготовка майбутніх лікарів у Словаччині починається відразу після закінчення ними університету та отримання диплома (6 років навчання для медичного факультету і 5 років для фармацевтичного і стоматологічного; програми навчання чітко відповідають європейським програмам згідно із принципами Болонської декларації). Після складен- 
ня державного іспиту студент отримує диплом лікаря (MDr - medical doctor) [7].

Першим етапом для лікарських спеціалізацій терапевтичного спрямування є проходження циклового післядипломного дворічного стажування у різних клініках, патронованих університетом (загальна медична спеціалізація), згідно із чітко регламентованим графіком, котрий передбачає паралельне навчання на кафедрах післядипломного рівня для відпрацювання теоретичних аудиторних занять (лекції, практичні заняття, семінари). Другим етапом є спеціалізаційне навчання на клінічній базі - стажування під контролем зовнішнього керівника-куратора.

Ці етапи складають так звану основну спеціалізацію, після якої лікар стає спеціалістом певного напрямку (наприклад, загальна хірургія, педіатрія, внутрішні хвороби, загальна практика, кардіологія, неврологія тощо; усього-63 фахи). Тривалість спеціалізації становить, як правило, ще 3-5 років, окрім спеціалізації із загальної практики (системи сімейної медицини у Словаччині на даний момент немає, ведуться суспільні та професійні дискусії), тривалість якої- 1 рік 3 місяці.

Програми спеціалізації розробляються й затверджуються міністерством охорони здоров'я в погодженні з університетом і так званими "рядітелями" (це спеціально призначений муніципальною владою розпорядник у своєму регіоні з питань медицини) i відповідають вимогам, затвердженим міністерством охорони здоров'я. Молодий лікар зараховується на посаду на основі рішення "рядітеля" згідно із запитом даного регіону на конкретну спеціалізацію, за якою у подальшому буде працювати даний фахівець, i отримує зарплатню з фонду муніципальної влади (даного конкретного лікувального закладу).

Кількість місць стажування на місцях є обмеженою і визначається відповідно до рівня акредитації лікувального закладу та потреб закладу. Стажування не передбачає оплати з фонду МO3, а діяльність здійснюється на основі адміністративно-правової угоди про працю. Наявність місць стажування публікується на сайті адміністрації регіону (муніципалітету).

Кожен лікар-стажист має визначеного керівника як в університеті (профільна кафедра), так і зовнішнього керівника - куратора спеціалізаційного навчання на клінічній базі - “гаранта подальшої освіти”. "Гарант" - це топ-менеджер з необхідним досвідом (понад 5 років) та ліцензією в передбаченій спеціалізацією галузі медицини (кандидатуру визначає “рядітель" - радник муніципалітету з питань медицини, затверджує MO3). До обов’язків гаранта належать сприяння реалізації навчальної програми в клініці та контроль її проходження, відповідальність за якість професійного навчання, керування професійною медичною практикою та оцінка продуктивності роботи кандидата. Він же дає пропозиції щодо наявності робочих місць відповідно до акредитації.

Таким чином, систему безперервного тематичного фахового навчання контролюють 3 трьох незалежних центрів: працівники кафедр післядипломної освіти (доцент-куратор); “гаранти” із клінік, де майбутній фахівець проходить стажування; державний координатор післядипломного навчання (представник МОЗу). Такий контроль унеможливлює будь-які спроби недобросовісного навчання чи одночасного проходження декількох спеціалізацій в різних закладах країни.

Складений індивідуальний план кожного лікаря-стажиста після затвердження в університеті та "рядітелем" на місці роботи має бути виконаним і контролюється куратором профільної кафедри університету, гарантом і “рядітелем" на місці роботи та деканатом університетів для додаткового та остаточного координування реалізації цих планів.

Після проходження базової спеціалізації у лікарівспеціалістів є можливість для подальшої післядипломної освіти за більш вузькою спеціалізацією (напр., нефрологія, трансплантологія, кардіологія тощо; усього - ще 18 фахів). Тривалість вторинної спеціалізації близько 3-х років. Згідно із досвідом Словаччини, кожен лікар після проходження спеціалізації має право додатково пройти ще декілька спеціалізацій за умови нормативного погодження з усіма координаторами.

Післядипломна спеціалізація передбачає також участь стажиста у чотирьох аудиторних тематичних теоретичних курсах (щонайменше 41 день). Обов'язковим для кожного з них є виконання та захист випускної спеціалізаційної роботи. Тема та завдання дослідницької діяльності визначаються керівником із профільної кафедри з урахуванням побажань стажиста й погоджуються із зовнішнім керівником із практичної бази.

Особливістю системи оцінювання знань лікарівстажистів у Словацькій Республіці є те, що немає бальної системи оцінки, є тільки поняття "зараховано”, "не зараховано”. У кінці стажування лікарі захищають випускну спеціалізаційну роботу та складають остаточний іспит, який відбувається при комісії, котра включає не тільки представника університету, але й декілька незалежних фахівців-практиків з регіону, де проходило стажування, а також 3 інших регіонів Словаччини. Це дає можливість неупереджено оці- 
нити рівень готовності до повної самостійної роботи молодого фахівця. Після цього лікар-стажист отримує титул MUDr - medical univercity doctor.

Зараз у Словацькій Республіці відбувається реформування післядипломної освіти, зокрема узгодження переліку фахів та строків спеціалізацій згідно з вимогами Болонської декларації, оскільки це країна Євросоюзу, та $€$ нагальна потреба можливості працевлаштування випускників цієї країни в інших країнах Європи [5].

Важливою складовою післядипломної освіти лікаря у Словаччині $є$ безперервна медична освіта лікарів протягом усього професійного життя. Куратором i координатором цього процесу виступає Словацька медична палата (SLS), яка є членом об’єднання медичних спеціалістів Європейського Союзу (UEMS) i забезпечує координацію післядипломної та безперервної освіти лікарів. Разом із Словацьким медичним університетом проводяться різні освітні заходи (курси, навчальні дискусії, семінари, тренінги і т. д.), які дозволяють їх учасникам отримати освітні кредити, підвищити їх кваліфікацію та обмінятися досвідом. На даному етапі за п'ять років практики лікарі Словаччини повинні отримати 250 кредитів, однак така практика не є обов'язковою для інших країн $С$.

У системі післядипломної освіти важливою ланкою $€$ докторантура. Основним завданням навчання у

\section{Література}

1. Підготовка сімейних лікарів на сучасному етапі: вирішені та невирішені проблеми / Г. І. Лисенко, О. Б. Ященко, Л. В. Хіміон [та ін. ] // Сімейна медицина. - 2011. - № 3. C. 5-6.

2. Шарабчиев Ю. Т. Организационно-правовые аспекты оказания первичной медико-санитарной помощи за рубежом. Сообщение 3 / Ю. Т. Шарабчиев, Т. В. Дудина // Медицинские новости. -2011. - № 1.-С. 31-40.

3. Ginter E. Social determinants of health in Slovakia / E. Ginter, K. Hulanska // Bratisl. Lek. Listy. - 2007. Vol. 108(10/11).-P. 477-479. докторантурі $€$ підготовка кадрів для здійснення наукових досліджень у тій чи іншій галузі медичного напрямку (клінічного чи неклінічного) із захистом наукової роботи і здобуттям наукового ступеня кандидата медичних наук (Csc, що відповідає рівню $\mathrm{PhD}$ в інших країнах). Це звання дає можливість викладачам ставати доцентами і професорами в університеті на основі виконання певних умов для цих посад. Звання доктор наук (Dsc) є більш високим рівнем визнання науковця і надається після виконання більш серйозних наукових досліджень, частіше на основі плідної наукової роботи у певній галузі.

Висновок. Цінним для України є досвід організації роботи системи охорони здоров'я у Словацькій Республіці на уніфікованих засадах країн СС та процесу підготовки кадрів для неї згідно з вимогами Болонської декларації у системі освіти, особливо в умовах реформування системи охорони здоров'я на засадах сімейної медицини та розмежування рівнів надання медичної допомоги населенню, а також інтеграції системи медичної освіти до Болонського процесу.

У перспективі подальших досліджень вважаємо за доцільне проаналізувати програму підготовки лікарів загальної практики у Словаччині для впровадження цього досвіду в Україні.

4. SzalayT. Slovakia: health system review. Health Systems in Transition / T. Szalay. - 2011. - P. 200.

5. Brekke M. Undergraduate medical education in general practice-family medicine throughout Europe - a descriptive study / M. Brekke// BMC Medical Education.-2013.-Vol. 13. - P. 157.

6. Evaluation of the structure and provision of primary care in Slovakia. A survey-based project,April, 2012. - P. 109.

7. Kristufek P. Twelve years of continuing medical education in Slovakia / P. Kristufek, J. Gajdosik // Vnitr. Lek. - 2010. Vol. 56(7).-P. 686-689. 